\title{
Kriteria Prioritas Pemilihan Teknologi Pengolahan Limbah Cair Industri Tempe
}

\author{
Cahyaning Kilang Permatasari \\ Teknik Industri, Fakultas Teknik, Universitas Nahdlatul Ulama, Surakarta, Indonesia \\ E-mail: kilangcahyaning@gmail.com
}

Informasi naskah:

Diterima

20 Juli 2021

Direvisi

01 Agustus 2021

Disetujui terbit

30 Agustus 2021

Diterbitkan

9 September 2021

\begin{abstract}
The location of tempe processing adjacent to the settlement causes problems. The resulting liquid waste makes people uncomfortable. This is presumably because the liquid waste has not been managed properly, because it is only dumped into the drainage channel. The majority of tempe industrial entrepreneurs are home industries who are not aware of creating a healthy environment by paying attention to liquid waste processing. There are many studies on technology for the tempe industrial wastewater problem, but each technology has advantages and disadvantages. It is necessary to have a system to choose the technology that suits the waste conditions. This research takes a case study in Karanganyar Regency. The Analytical Hierarchy Process (AHP) method is a method of determining priority scale that can accommodate all aspects. Furthermore, a sequence of criteria can be arranged as needed. The results of the analysis with AHP are: technology criteria $31.09 \%$; environment 28.65\%; economic $21.74 \%$ and social $18.53 \%$. Environmental sub-criteria showed the results of the removal of ammonia $40.56 \%$; treated water quality $30.74 \%$; the amount of mud is $18.91 \%$ and the emission level is $9.80 \%$. Technology sub-criteria are ease of operation $28.67 \%$; land area requirement $28.56 \%$; service life of $28.05 \%$ and the potential of technology in the midification of $14.72 \%$. Economic sub-criteria with the results of operating costs $34.21 \%$; installation cost 33.28\%; maintenance costs $23.78 \%$ and HR costs $8.73 \%$. Social sub-criteria with the results of the need for employment of $49.10 \%$; readiness of human resources $19.33 \%$; implementation of construction $16.74 \%$ and aesthetics $14.82 \%$. The results of the AHP can be used as input for tempe entrepreneurs, the government and the community to improve the environmental quality of the tempe industrial wastewater. It is hoped that entrepreneurs will find it easier to determine the appropriate technology to treat the tempe industrial liquid waste.
\end{abstract}

Keywords: AHP, Liquid waste, Tempe Industry, Drainage, Environment 


\section{PENDAHULUAN}

\subsection{Latar Belakang Masalah}

Lokasi pengolahan tempe yang bersandingan dengan pemukiman penduduk, seiring berjalannya waktu menimbulkan permasalahan dari segi lingkungan. Limbah cair yang dihasilkan oleh industri tempe sangat berpengaruh kepada kenyamanan masyarakat sekitarnya. Hal ini diduga karena limbah cair yang dihasilkan belum dikelola dengan baik dan dibuang di saluran drainase. Seperti yang diungkapkan oleh Rozikin di Tempo.Co, Jakarta.Kamis, 26 September 2019, 06:24 WIB, yang mengatakan ada sekitar 200 pengusaha tempe di Kampung Tempe di RT 06, 08 dan 12 RW 03 Sunter Jaya ${ }^{1)}$. Seluruh pengusaha tempe, langsung membuang limbahnya ke saluran penghubung yang bermuara di Kali Item. Warga di Kampung Tempe hanya membuat saluran penghubung berdiameter 30-50 sentimeter untuk mengalirkan air limbah tempe ke drainase yang lebih besar dengan diameter sekitar 1,5-2 meter. Ratusan pengusaha tempe di Kampung Tempe belum mengolah limbah usaha mereka. Selain itu, dituliskan Suarajogja.id. Senin, 15 Juni 2020, 15:30 WIB, Ketua RW 05, Padukuhan Besari, Kelurahan Siraman, Suparman mengeluhkan adanya pencemaran sungai cukup parah terjadi di wilayahnya akibat industri olahan kedelai ${ }^{2}$. Hal ini sudah terjadi sejak tiga tahun ke belakang. Pada tahun 2019 kondisinya lebih buruk lantaran ekosistem sungai mati. Saat ini ada empat pabrik tahu dan tempe yang beroperasi di area dekat sungai.

Pengusaha industri tempe yang mayoritas adalah industri rumah tangga perlu kesadaran untuk menciptakan lingkungan sehat dengan memperhatikan pengolahan limbah cair yang dihasilkan. Hal ini sesuai dengan Peraturan Menteri Lingkungan Hidup Republik Indonesia No.5 Tahun 2014 Tentang Baku Mutu Air Limbah, Baku Mutu Air Limbah Bagi Usaha Dan/Atau Kegiatan Pengolahan Kedelai ${ }^{3)}$. Indikator pencemar bahan organik ditandai oleh parameter BOD, COD, TSS, dan $\mathrm{pH}$. Telah banyak penelitian tentang teknologi untuk menyelesaikan permasalahan limbah cair industri tempe. Salah satunya adalah Indah Nurhayati, dkk tahun 2011 di Kabupaten Sidoarjo menyatakan bahwa pengolahan limbah industri tempe setelah diolah dengan biofilter diperoleh hasil yang sangat memuaskan dengan efisiensi penurunan rata-rata 98\%, untuk parameter BOD, COD, TSS, sehingga efluen yang dibuang ke sungai sudah memenuhi baku mutu sesuai dengan SK. Gub. Jatim No. 136 tahun 1994, Tentang Baku Mutu Limbah Cair Industri ${ }^{4)}$. IPAL untuk mengolah limbah cair industri tempe menjadikan lingkungan sekitar industri menjadi lebih baik, pemilik industri tempe merasa aman dari ancaman protes masyarakat karena limbah cair industrinya tidak mengganggu lingkungan sekitar. Namun setiap teknologi mempunyai kelebihan dan kekurangan, maka perlu dibuat satu sistem untuk memilih teknologi yang sesuai dengan kondisi limbah tersebut.

Pada penelitian ini akan dilakukan studi kasus di Kabupaten Karanganyar, karena di lokasi tersebut ada beberapa pengusaha tempe yang belum mengerti akan teknologi pengolahan limbah cair tempe. Metode Analitycal Hierarchy Process (AHP), adalah 
sebuah metode penentuan skala prioritasyang dapat menampung semua aspek. Selanjutnya diharapkan dapat disusun urutan kriteria yang sesuai kebutuhan. Kriteria ini mengkombinasi beberapa aspek berdasarkan tingkat kepentingan, sehingga hasil urutan pemilihan nantinya lebih obyektif. Hasil dari AHP dapat digunakan sebagai masukan dan referensi kepada pengusaha tempe, pemerintah setempat dan masyarakat dalam rangka peningkatan kualitas lingkungan yang berkaitan dengan limbah cair industri tempe. Hal ini bertujuan untuk kelangsungan industri tempe kedepannya dan meminimalkan permasalahan dimasa depan.Dengan mengetahui prosentase prioritas kriteria yang harus diutamakan dalam upaya penyelamatan drainase, diharapkan para pengusaha akan lebih mudah saat menentukan teknologi yang cocok untuk mengolah limbah cair industri tempe.

\subsection{Identifikasi Permasalahan}

Rumusan masalah penelitian ini adalah :

1. Bagaimana kondisi lingkungan sekitar lokasi industri tempe ?

2. Bagaimana penilaian kriteria dan sub kriteria yang mempengaruhi pengambilan keputusan sebagai prioritas pemilihan tekhnologi pengolahan limbah cair industri tempe?

\subsection{Batasan Penelitian}

Batasan masalah dalam penelitian ini sebagai berikut :

1. Objek pengamatan adalah di Lingkungan Wonorejo, Kabupaten Karanganyar.

2. AnalisisAHP hanya pada kriteria dan sub kriteria.

\subsection{Tujuan dan Manfaat Penelitian}

Tujuan penelitian ini adalah :

1. Mengetahui kondisi wilayah penelitian.

2. Mengetahui penilaian kriteria dan sub kriteria yang mempengaruhi pengambilan keputusan sebagai prioritas pemilihan tekhnologi pengolahan limbah cair industri tempe.

\section{METODE}

Penelitian ini dilakukan dengan mengamati lokasi di Lingkungan Wonorejo, Kabupaten Karanganyar Provinsi Jawa Tengah. Jenis penelitian yang dilakukan ialah penelitian deskriptif. Penelitian deskriptif adalah penelitian dengan menggunakan metode untuk menggambarkan suatu hasil penelitian ${ }^{5}$. Namun, hasil gambaran tersebut tidak digunakan untuk membuat kesimpulan yang lebih umum. Objek yang diamati dalam penelitian ini adalah pengolahan limbah cair pada industri tempe.

\subsection{Pengumpulan Data}

Metode pengumpulan data yang digunakan pada penelitian ini adalah: 
1. Observasi adalah metode pengumpulan data dengan cara mengamati secara cermat dan langsung di lokasi penelitian untuk mengetahui kondisi yang terjadi atau membuktikan kebenaran dari sebuah desain penelitian yang dilakukan. ${ }^{6}$.

2. Wawancara untuk mendapatkan informasi secara langsung dengan mengungkapkan pertanyaan pada para responden. Wawancara dilakukan kepada responden, responden dipilih berdasarkan non-probability sampling yang digunakan yaitu purposive sampling dengan tipe judgement sampling yaitu pertimbangan tertentu misalnya karena kemampuannya atau kelebihannya di antara orang-orang lain dalam memberikan data dan informasi yang bersifat khusus yang dibutuhkan peneliti. Pertanyaan yang diberikan tentang informasi awal lokasi penelitian dan beberapa aspek yang akan dijadikan pertanyaan untuk menyusun kuesioner ${ }^{7)}$.

3. Kuesioner merupakan teknik pengumpulan data dengan cara memberi seperangkat pertanyaan atau pernyataan secara tertulis kepada responden. Kuesioner yang digunakan dalam penelitian ini adalah dengan skala AHP yang dibagikan langsung kepada responden. Jumlah responden pada penelitian ini adalah $10 \% \mathrm{x}$, jadi ada 24 responden yang terdiri dari Bidang Tata Ruang DPUPR, Bidang Cipta Karya DPUPR, Laboratorium DLH, pengusaha tempe, staff Primer Koperasi Produsen Tempe dan Tahu Indonesia, perwakilan masyarakat ${ }^{8)}$.

\subsection{Instalasi Pembuangan Air Limbah}

Beberapa teknologi untuk mengolah limbah organik, khususnya pengolahan limbah cair yang sesuai untuk limbah cair industri pangan skala kecil, seperti: sistem lumpur aktif, sistem trikling filter, sistem RBC (Rotating Biolocal Disk), sistem SBR (Sequencing Batch Reactor), sistem UASB dan Anaerobik lagoon" ${ }^{9}$. Sistem aerobik (lumpur aktif, Trikcling Filter, Rotating Biological Contactor (RBC)) dan sistem anaerobik (Anaerobik lagoon, sistem SBR (Sequencing Batch Reactor), Proses upflow anaerobic sludge blanket (UASB) 10). Setiap sistem mempunyai keunggulan dan kelemahan, dan pemanfaatannya membutuhkan kesesuaian dengan permasalahan yang dihadapi. Pada umumnya pertanyaan yang muncul berkisar pada : kemampuan alat dalam menurunkan kadar pencemaran hingga memenuhi baku mutu yang berlaku, biaya investasi dan operasi yang dibutuhkan, kemudahan dalam perawatan dan suku cadang, dan kebutuhan lahan.

Kriteria mengacu pada aspek umum yang dianggap relevan untuk mencapai tujuan, kriteria terdiri dari aspek lingkungan, teknologi, ekonomi dan sosial.

1. Aspek Lingkungan

Kriteria aspek lingkungan terkait dengan kompatibilitas lingkungan pabrik dengan wilayah sekitarnya. Kriteria khusus mengacu pada unsur-unsur berikut, yaitu kadar yang terkandung dalam air seperti nitrogen, fosfor, dan kandungan lainnya, buangan yang dikeluarkan ke udara (emisi). Menurut Molinos dalam Akmaliah menyatakan bahwa kadar lumpur limbah merupakan salah satu kriteria aspek lingkungan ${ }^{11)}$. 


\section{Aspek Tekhnologi}

Kriteria aspek teknis menggambarkan semua parameter teknis terpenting dari teknologi yang berbeda, dengan mengacu pada data kualitatif dan kuantitatif dan indeks kinerja. Pada aspek teknis, kriteria yang dipertimbangkan, yaitu kompleksitas sistem menunjukkan kemampuan kinerja teknologi. Curiel dalam Akmaliah menyebutkan aspek teknologi juga dipengaruhi oleh faktor luas area dan daya tahan ${ }^{11)}$. Dalam sumber referensi lain juga menyebutkan kemudahan operasional dan masa layan sistem ${ }^{12}$.

3. Aspek Ekonomi

Untuk aspek ekonomi, kriteria spesifik yang telah dipertimbangkan antara lain, yaitu biaya investasi yang mengacu pada biaya moneter yang diperlukan untuk pembangunan pabrik dan biaya operasi terkait dengan manajemen instalasi pengolahan, dan biaya yang digunakan untuk perawatan sistem. Curiel dalam Akmaliah menyebutkan aspek ekonomi juga dipengaruhi oleh faktor biaya pekerja ${ }^{11)}$.

4. Aspek Sosial

Faktor sosial dan budaya sulit untuk diukur akan tetapi faktor ini mempunyai peran penting dalam penerapan teknologi yang akan digunakan dalam mengolah air limbah, karena buangan dari pengolahan ini akan bersentuhan langsung dengan masyarakat. Tujuan dari aspek sosial budaya ini untuk memenuhi kebutuhan manusia dalam hal spiritual maupun budaya, dalam hal ini moral agar hubungan dengan masyarakat dapat terjalin dengan stabil. Dalam penelitian Wilma, 2016, menyebutkan aspek sosial dapat dilihat dari penyerapan tenaga kerja, minim dalam timbulnya konflik antar masyarakat, dan kesesuaian dengan budaya setempat ${ }^{12)}$. Kriteria sosial terkait dengan kompatibilitas lingkungan pabrik dengan wilayah sekitarnya adalah dampak pada setiap tahapan pembangunan IPAL dan estetika pada pembangunan IPAL ${ }^{13)}$.

\subsection{Prinsip Dasar Analytical Hierarchy Process (AHP)}

Pertama adalah penyusunan hierarki. Dengan hirarki, suatu masalah yang kompleks dapat diuraikan ke dalam kelompok-kelompoknya yang kemudian diatur menjadi suatu bentuk hirarki sehingga permasalahan akan tampak lebih terstruktur dan sistematis ${ }^{14}$. Menurut Saaty (1994) dalam Hanien Nia H Sega (2012) menjelaskan hirarki adalah gambaran permasalahan yang kompleks dalam struktur banyak tingkat, tingkat paling atas adalah tujuan dan diikuti tingkat kriteria lalu subkriteria dan seterusnya sampai pada tingkat yang paling bawah adalah tingkat alternatif ${ }^{15)}$. Berdasarkan latar belakang pada pendahuluan dapat ditentukan kriteria yang akan digunakan dalam "Kriteria Prioritas Dalam Pemilihan Tekhnologi Pengolahan Limbah Cair Industri Tempe" dapat digambarkan dalam bagan skema hierarki "Penerapan AHP Dalam Menentukan Lokasi Pabrik Tempe" ditunjukkan pada Gambar 1: 


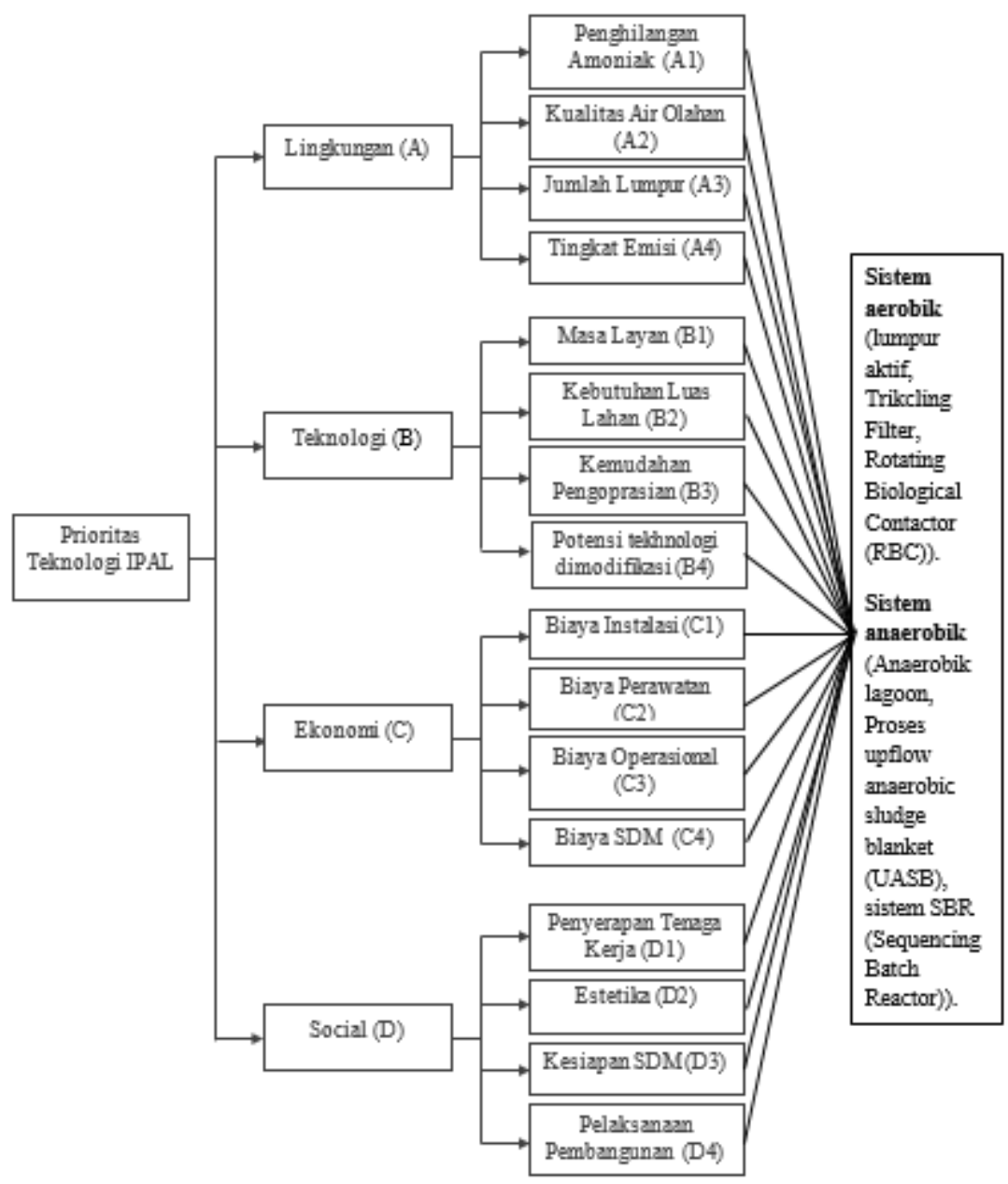

Gambar 1. Skema Hirarki

Kedua yaitu penilaian terhadap criteria. Dalam melakukan perhitungan dengan metode AHP, untuk mengkuantitatifkan pendapat kualitatif digunakan skala penilaian sehingga akan diperoleh nilai pendapat dalam bentuk angka atau kuantitatif. ${ }^{16}$ Menurut Saaty (1986) untuk berbagai permasalahan skala 1 sampai dengan 9 merupakan skala terbaik dalam mengkualitatifkan pendapat, dengan akurasinya berdasarkan nilai RMS (Root Mean Square Deviation) dan MAD (Median Absolute Deviation).

Ketiga adalah penentuan bobot kriteria dan prioritas pembuktian konsistensi perbandingan berpasangan dengan AHP. Langkah-langkahnya sebagai beikut : $\mathrm{a}(\mathrm{ij})=\mathrm{Ai} / \mathrm{Aj}$, dengan $: \mathrm{i}, \mathrm{j}=1,2,3, \ldots \mathrm{n}$

$\mathrm{Wi}=\mathrm{n} \sqrt{(\text { ai } 1} \mathrm{x}$ ai2 $\mathrm{x}$ ai3 $3, \ldots \mathrm{x}$ ain $)$

$\mathrm{Xi}=(\mathrm{Wi} / \Sigma \mathrm{Wi})$

$\lambda m a k s=\Sigma$ aij.Xj 
Terakhir adalah pembuktian konsistensi perbandingan dengan perhitungan kontrol terhadap Indek Consistensi (CI) dan Ratio Consistensi (CR) ${ }^{17)}$.

- Indek Consistensi $(\mathrm{CI})=(\lambda$ maks. $-\mathrm{n}) /(\mathrm{n}-1)$, dimana $\mathrm{n}=$ ukuran matrik.

- Ratio Consistensi (CR) = CI/RI, Nilai Ratio Consistensi (CR) harus lebih kecil dari $10 \%$, sesuai dengan syarat konsistensi yaitu harus lebih kecil dari 0,1 atau $10 \%$.

AHP sebagai salah satu metode analisis terdapat beberapa kelebihan dan kekurangan. Kelebihan metode AHP adalah struktur yang berhierarki, memperhitungkan validitas hingga batas toleransi inkonsistensi kriteria dan alternatif, memperhitungkan ketahanan output analisis sensitivitas pengambilan keputusan ${ }^{18)}$. Selain itu memperhitungkan validitas sampai dengan batas toleransi inkonsistensi sebagai kriteria dan alternatif yang dipilih oleh pengambil keputusan dan memperhitungkan daya tahan output analisis sensitivitas pengambilan keputusan. Hal ini sesuai dengan penelitian yang telah dilakukan oleh Suci Oktri Viarani, 2015 bahwa metode AHP (Analytical Hierarchy Process) merupakan metode yang sistematis dan tidak membutuhkan waktu yang lama, serta dapat memperlihatkan bobot prioritas dari kriteria dan pemasok yang terpilih ${ }^{19)}$.

Ketergantungan model AHP pada input utamanya berupa persepsi seorang ahli, sehingga dalam hal ini melibatkan subyektifitas sang ahli. Selain itu, model menjadi tidak berarti jika ahli tersebut memberikan penilaian yang keliru. Metode AHP ini hanya metode matematis tanpa ada pengujian secara statistik sehingga tidak ada batas kepercayaan dari kebenaran model yang terbentuk ${ }^{20)}$.

\section{PEMBAHASAN DAN DISKUSI}

\subsection{Kondisi Wilayah Penelitian}

Ada 12 indutri tempe di Lingkungan Wonorejo yang membuang limbah cairnya di saluran drainase, jika setiap hari per industry mengolah 50 sampai $100 \mathrm{~kg}$ kedelai maka untuk 12 industri akan ada produksi tempe antara 600 sampai $1000 \mathrm{~kg}$. Jika tidak ada kesadaran untuk menerapkan prinsip produksi bersih serta membuang air limbah yang mengandung polutan ke saluran drainase maka akan mengancam lingkungan sekitar. Keresahan masyarakat juga meningkat di musim kemarau, karena air limbah yang dibuang di saluran drainase tidak dapat mengalir dengan lancar dan menggenang di beberapa titik saluran drainase dan menimbulkan bau tidak sedap. Lingkungan Wonorejo adalah lokasi paling banyak terdapat industri tempe skala rumah tangga yang belum mempunyai sistem pengolahan limbah.

\subsection{Penilaian Kriteria Dan Sub Kriteria}

Perhitungan Control terhadap Indek Consistensi (CI) dan Ratio Consistensi (CR).

- Indek Consistensi $(\mathrm{CI})=(\lambda$ maks. $-\mathrm{n}) /(\mathrm{n}-1)$, dimana $\mathrm{n}=$ ukuran matrik $4 \mathrm{x} 4$

- Ratio Consistensi $(\mathrm{CR})=\mathrm{CI} / \mathrm{RI}$, untuk $\mathrm{n}=4$, maka RI $=0,9$. Nilai Ratio Consistensi (CR) lebih kecil dari 0,1 sama artinya lebih kecil dari 10\%, maka nilai tersebut sudah sesuai dengan syarat konsistensi yaitu harus lebih kecil dari 0,1 atau $10 \%$. 
Tabel 1 Control CI dan CR

\begin{tabular}{cccccc}
\hline $\begin{array}{c}\text { Konsistensi } \\
\text { Perbandingan }\end{array}$ & Kriteria & $\begin{array}{c}\text { Sub kriteria } \\
\text { A }\end{array}$ & $\begin{array}{c}\text { Sub kriteria } \\
\text { B }\end{array}$ & $\begin{array}{c}\text { Sub kriteria } \\
\text { C }\end{array}$ & $\begin{array}{c}\text { Sub kriteria } \\
\text { D }\end{array}$ \\
\hline CI & 0,06 & 0,08 & 0,09 & 0,04 & 0,05 \\
CR $<0,10$ & 0,07 & 0,09 & 0,10 & 0,05 & 0,05 \\
Konsisten & Ya & Ya & Ya & Ya & Ya \\
\hline
\end{tabular}

Dari Tabel 1 dapat dilihat bahwa penilaian Responden terhadap beberapa kriteria dan sub kriteria adalah konsisten. Jika semua perbandingan sudah konsisten maka dapat dilanjutkan dengan perhitungan bobot kriteria dan sub kriteria.Hasil dari bobot prioritas untuk kriteria dan sub kriteria disajikan pada Tabel 2.

Tabel 2 Bobot Prioritas

\begin{tabular}{|c|c|c|}
\hline \multirow{4}{*}{ Kriteria } & $\mathrm{d}^{\prime}(\mathrm{A})$ & 1,20 \\
\hline & $\mathrm{d}^{\prime}(\mathrm{B})$ & 1,30 \\
\hline & $\mathrm{d}^{\prime}(\mathrm{C})$ & 0,91 \\
\hline & $\mathrm{d}^{\prime}(\mathrm{D})$ & 0,78 \\
\hline \multirow{4}{*}{ Sub kriteria A } & $\mathrm{d}^{\prime}(\mathrm{A} 1)$ & 1,72 \\
\hline & $d^{\prime}(\mathrm{A} 2)$ & 1,31 \\
\hline & $\mathrm{d}^{\prime}(\mathrm{A} 3)$ & 0,80 \\
\hline & $d^{\prime}(\mathrm{A} 4)$ & 0,42 \\
\hline \multirow{4}{*}{ Sub kriteria B } & $\mathrm{d}^{\prime}(\mathrm{B} 1)$ & 1,20 \\
\hline & $\mathrm{d}^{\prime}(\mathrm{B} 2)$ & 1,22 \\
\hline & $\mathrm{d}^{\prime}(\mathrm{B} 3)$ & 1,22 \\
\hline & $\mathrm{d}^{\prime}(\mathrm{B} 4)$ & 0,63 \\
\hline \multirow{4}{*}{ Sub kriteria C } & $\mathrm{d}^{\prime}(\mathrm{C} 1)$ & 1,37 \\
\hline & $\mathrm{d}^{\prime}(\mathrm{C} 2)$ & 0,98 \\
\hline & $\mathrm{d}^{\prime}(\mathrm{C} 3)$ & 1,41 \\
\hline & $\mathrm{d}^{\prime}(\mathrm{C} 4)$ & 0,36 \\
\hline \multirow{4}{*}{ Sub kriteria D } & $\mathrm{d}^{\prime}(\mathrm{D} 1)$ & 2,04 \\
\hline & $\mathrm{d}^{\prime}(\mathrm{D} 2)$ & 0,61 \\
\hline & $\mathrm{d}^{\prime}(\mathrm{D} 3)$ & 0,80 \\
\hline & $\mathrm{d}^{\prime}(\mathrm{D} 4)$ & 0,69 \\
\hline
\end{tabular}

Hasil dari bobot prioritas untuk kriteria yang telah dinormalisasikan disajikan pada Tabel 3. 


\begin{tabular}{lrc}
\multicolumn{3}{c}{ Tabel 3 Bobot Tiap Kriteria dan Sub Kriteria } \\
\hline \multicolumn{3}{c}{ Kriteria } \\
Lingkungan & 28,65 & $\%$ \\
Teknologi & 31,09 & $\%$ \\
Ekonomi & 21,74 & $\%$ \\
Sosial & 18,53 & $\%$ \\
\hline \multicolumn{3}{c}{ Sub Kriteria A } \\
Penghilangan Amoniak & 40,56 & $\%$ \\
Kualitas Air Olahan & 30,74 & $\%$ \\
Jumlah Lumpur & 18,91 & $\%$ \\
Tingkat Emisi & 9,80 & $\%$ \\
\hline \multicolumn{3}{c}{ Sub Kriteria B } \\
Masa Layan & 28,05 & $\%$ \\
Kebutuhan Luas Lahan & 28,56 & $\%$ \\
Kemudahan Pengoprasian & 28,67 & $\%$ \\
Potensi Tekh. Dimodifikasi & 14,72 & $\%$ \\
\hline \multicolumn{3}{c}{ Sub Kriteria C } \\
Biaya Instalasi & 33,28 & $\%$ \\
Biaya Perawatan & 23,78 & $\%$ \\
Biaya Operasional & 34,21 & $\%$ \\
Biaya SDM & 8,73 & $\%$ \\
\hline \multicolumn{2}{c}{ Sub Kriteria D } \\
Penyerapan Tenaga Kerja & 49,10 & $\%$ \\
Estetika & 14,82 & $\%$ \\
Kesiapan SDM & 19,33 & $\%$ \\
Pelaksanaan Pembangunan & 16,74 & $\%$ \\
\hline
\end{tabular}

Hasil perhitungan pembobotan kriteria dengan metode AHP adalah kriteria teknologi 31,09\%; lingkungan 28,65\%; ekonomi 21,74\% dan sosial 18,53\%. Kriteria Teknologi menjadi prioritas utama dalam penelitian ini. Kriteria teknologi sangat berperan dalam penentuan pengambilan keputusan prioritas teknologi IPAL karena teknologi yang dipilih berpengaruh langsung terhadap kelangsungan aktifitas IPAL.

Sub kriteria teknologi menghasilkan pembobotan dengan urutan kemudahan pengoprasian, kebutuhan luas lahan, masa layan dan potensi teknologi dimodifikasi. Kemudahan pengoprasian menjadi sub kriteria yang diutamakan karenaindustry tempe ini merupakan industri kecil skala rumahan jadi yang terpenting adalah teknologi IPAL mudah dioprasikan tanpa harus mengikuti banyak pelatihan tentang IPAL. Sub kriteria lingkungan menghasilkan urutan penghilangan amoniak, kualitas air olahan, jumlah lumpur dan tingkat emisi. Kriteria lingkungan mengindikasikan penghilangan amoniak menjadi prioritas utama karena amoniak industri tempe menjadikan ciri khas limbah tempe yang dikenal menjadi sumber ketidaknyamanan masyarakat disekitarnya. Sub kriteria ekonomi mengindikasikan biaya operasional adalah prioritas utama, dikarenakan biaya operasional akan dikeluarkan setiap harinya jadi sebisa mungkin IPAL dengan biaya operasional 
termurah yang akan digunakan pada industri tempe. Sub kriteria sosial menunjukkan penyerapan tenaga kerja menjadi prioritas karena dengan dibangunnya IPAL akan dapat membuka lowongan kerja disekitar wilayah tersebut.

Setelah dilakukan penilaian bobot kriteria dan subkriteria diharapkan pengusaha dan pemerintah dapat menentukan teknologi IPAL yang akan digunakan di lingkungan Wonorejo sebagai penanganan limbah cair industri tempe yang selama ini dibuang langsung tanpa pengolahan ke saluran drainase.

\section{KESIMPULAN}

Ada 12 industri tempe dengan total produksi 600 sampai $1000 \mathrm{~kg}$ per hari yang membuang air limbahnya di saluran drainase yang mengancam lingkungan sekitarnya. Skala prioritas perbaikan saluran drainase dari limbah cair industri tempe dengan metode AHP yaitu kriteria teknologi 31,09\%; lingkungan 28,65\%; ekonomi 21,74\% dan sosial $18,53 \%$. Sedangkan subkriteria Lingkungan menunjukan hasil penghilangan amoniak 40,56\%; kualitas air olahan 30,74\%; jumlah lumpur 18,91\% dan tingkat emisi 9,80\%. Selanjutnya subkriteria tekhnologi adalah kemudahan pengoprasian 28,67\%; kebutuhan luas lahan 28,56\%; masa layan 28,05\% dan potensi teknologi di modifikasi 14,72\%. Subkriteria ekonomi dengan hasil biaya operasional $34,21 \%$; biaya instalasi $33,28 \%$; biaya perawatan 23,78\% dan biaya SDM 8,73\%. Terakhir adalah subkriteria sosial dengan hasil kebutuhan penyerapan tenaga kerja 49,10\%; kesiapan SDM 19,33\%; pelaksanaan pembangunan16,74\% dan estetika 14,82\%. Dari hasil penelitian, pembahasan dan kesimpulan yang ada, maka dapat disampaikan beberapa saran guna tercapainya drainase yang sehat sesuai fungsinya antara lain sosialisasi dan kebijakan terhadap UMKM skala rumahan lain yang limbahnya menimbulkan pencemaran lingkungan perlu dilakukan oleh pemerintah setempat.

\section{UCAPAN TERIMA KASIH}

Terimakasih kepada pengusaha tempe, anggota Primkopti, perwakilan masyarakat, Staff DPUPR, Staff DLH Kab. Karanaganyar sebagai responden yang telah berkenan meluangkan waktunya untuk mengisi kuesioner, sehingga penelitian ini dapat terlaksana dengan baik.

\section{DAFTAR PUSTAKA}

1) Hamdi, Imam dan Chairunisa, Ninis. 2019. Ratusan Pengusaha Tempe di Sunter Masih Buang Limbah ke Kali Item. Tempo.Co, Jakarta. Diakses : Maret 2021.

2) Julianto. 2020. Diduga Tercemar Limbah Tempe, Ekosistem di Sungai Wonosari Rusak Parah. Suarajogja.id. Diakses : Maret 2021.

3) Peraturan Menteri Lingkungan Hidup Republik Indonesia No.5 Tahun 2014 Tentang Baku Mutu Air Limbah.

4) Nurhayati, Indah, dkk. 2011. Pengolahan Air Limbah Pabrik Tempe Dengan Biofilter. Jurnal Teknik. Volume 09 Nomor 02-Juli 2011-ISSN : 1412-1867. 
5) Sugiyono. 2013. Metode Penelitian Pendidikan Pendekatan Kuantitatif, Kualitatif, dan R\&D. Alfabeta. Bandung.

6) https://raharja.ac.id/2020/11/10/observasi/. Diakses : Oktober 2021.

7) Subagyo, P.Joko. 2011. Metodologi Penelitian Dalam Teori Dan Praktek. Aneka Cipta. Jakarta.

8) Sugiyono. 2005. Metode Penelitian Kuantitatif Kualitatif Dan R\&D. Alfabeta. Bandung.

9) Direktorat jenderal Industri Kecil Menengah. 2007. Pengelolaan Limbah Industri Pangan.. Jakarta.

10) Herlambang, Arie. 2014. Teknologi Pengolahan Limbah Cair Industri Tahu Tempe. Paket Informasi Teknologi.

11) Akmaliah, Vina. 2018. Penilaian Teknologi Pengolahan Limbah Cair Pada Pabrik Karet Dengan Menggunakan Metode Analytical Hierarchy Process Dan Promethee. Skripsi Universitas Sumatra Utara.

12) Adzillah, Wilma Nurul, dkk. 2016. Pemilihan Alternatif Pengolahan Limbah Cair Domestik Dengan Menggunakan Metode DPPA dan ANP. Jurnal Teknik Sipil dan Lingkungan. Volume 22 Nomor 2, Oktober 2016. ITB. Bandung.

13) Pedoman Teknis Penyusunan Kelayakan SPAL. 2016. Cipta Karya.

14) http://eprints.umg.ac.id/2185/3/BAB\%20II.pdf. Diakses : Maret 2021.

15) Sega, Hanien Nia H, dkk. 2012. Penentuan Faktor Prioritas Mahasiswa Dalam Memilih Telepon Seluler Merk Blackberry Dengan Fuzzy AHP. Jurnal Jurusan Statistika, FSM, Universitas Diponegoro. Semarang.

16) Saaty, 1986. The Analytic Hierarchy Process. McGraw-Hill.

17) Saaty, T.L. 1993. Pengambilan Keputusan bagi Para Pemimpin, Proses Analitik Untuk Pengambilan Keputusan Dalam Situasi Yang Kompleks. Pustaka Binaman Prestindo. Jakarta.

18) Parhusip, Jadiaman. 2019. Penerapan Metode Analytical Hierarchy Process (AHP) Pada Desain Sistem Pendukung Keputusan Pemilihan Calon Penerima Bantuan Pangan Non Tunai (BPNT) Di Kota Palangka Raya. Jurnal Teknologi Informasi Jurusan Teknik Informatika, Kampus UPR Tunjung Nyaho. Vol 13 No 2 ISSN 1907896X, Agustus 2019.

19) Viarani, Suci Oktri dan Hilma Raimona Zadry. 2015. Analisis Pemilihan Pemasok Dengan Metode Analitycalhierarchyprocess Di Proyek Indarung VI PT Semen Padang. Jurnal Laporan Kerja Praktek. Jurusan Teknik Industri, Fakultas Teknik, Universitas Andalas, Padang., Vol. 14 No.1, April 2015:55-70. ISSN 20884842/2442-8795.

20) Munthafa, Agnia Eva dan Husni Mubarok. 2017. Penerapan Metode Analytical Hierarchy Process Dalam Sistem Pendukung Keputusan Penentuan Mahasiswa Berprestasi. Jurnal Siliwangi Jurusan Teknik Informatika Universitas Siliwangi. Vol.3. No.2, 2017 Seri Sains dan Teknologi. ISSN 2477-3891. 